\title{
Corporate Governance and Banks' Turmoils: Assessment of Shareholders Response
}

\author{
Ikoh, Itoro Moses \\ Banking \& Finance/ Insurance Department \\ Faculty of Business Administration \\ University Of Uyo, Uyo-Nigeria \\ Nsien, Christiana Ben \\ Dept. of Business Education \\ School of Vocational and Technical Education \\ College of Education, Akwa I bom State, Nigeria \\ Wokoma Tamuno-Inam Nicholas \\ Department of Accounting \\ Faculty of Management Sciences \\ University of Calabar, Calabar-Nigeria
}

\section{Doi:10.5901/jesr.2013.v3n8p39}

Abstract

Cooperate governance is seen as the mechanism of control for harnessing the ugly face of bank turmoil's. It can persuade, induce complete and motivate corporate managements in order to eliminate the corporate deviance and turmoil in the banks. It is a system and power for decision making, risk monitoring, setting of objectives and policies and the assessment of overall bank internal and external performance and control optimization. The study made use of secondary data obtained from 5 commercial banks on the assessment of their corporate board members. We subjected their responses on a 6-point Likert scale measurement into a Pearson Product Moment Correlation Test as well as t-test. The result of the findings revealed that good corporate governance of banks will reduced mistrust between shareholders and management but may not reduce the overall bank turmoil. This is because of other variables associated with bank turmoil's. The study recommends that corporate governance can only prevent banking turmoil's with adequate implementation of code of corporate governance for best practices in Banks, understanding and diligent discharged of responsibility in a prudent and transparent manner. Finally the study recommends that our banks board of directors and management team should be abreast with adequate, relevant and needed knowledge, experiences, professional skills, competences in order to remove in total the bank turmoils.

Keywords: Poor corporate governance, bank turmoils, bank performance, sustainable corporate growth.

\section{Introduction}

Turmoils in the Nigerian banking institution can be traced to the financial scandals around the world. The recent collapse of major corporate institutions in the United States of American and Europe affected the Nigerian Banking sector through the trickle down syndrome. In the $21^{\text {st }}$ 
century, the world is fast becoming a global village; and so the financial crises which began when the credit market came to a standstill in July 2007 in the United States and United Kingdom, exerts a huge impact on the rest of the world financial market, including that of Nigeria (Angonleas, 2008, cited in Ifeanyi, Olagunjv, A. \& Adeyanji, 2011) According to them, the crisis which brew for a while started to show its effect in the middle of 2008; but around the world stock market were falling, large financial institution had collapsed. Government in even the wealthiest nations have had to come with rescue packages, to bail out their financial system. It created a significant relationship between government and business firms and justifies the necessity for government regulatory functions, if only, to avoid the re-occurrence of financial turmoils.

Although the recent banking failures became a universal case, it was not a new development in the Nigeria Banking Institutions. A survey of literature shows that between 1986 and 2012, most banks in Nigeria had lost their confidence and credibility among share-holders and customer-public, reminiscences of banking industry in the 1950s economic crisis, which witnessed the failure of indigenous banks after the 1930 economic depression. On a specific note, it has been reported that (7) seven banks were distressed in 1989; (9) nine in 1990; (8) eight in 1991; (13) thirteen in 1992; (24) twenty four in 1993; (5) five in 1995, (26) twenty six in 1998 and (3) three in 2011. In all (124) one hundred and twenty four banks were distress. These were indeed turmoils.

In order to safeguard against banks failures, good governance in the banking industry was designed to be turmoil resolution. It is a systematic programme action put in place to resolve the distress state of the banking institutions, to maintain public credibility, confidence and stability in the banking system, ensure fairness, equity, transparency and accountability and instill market discipline (Oluyei, 2005). It also discharge moral hazards and achieve minimum disruption or banking services (Ifeanyi, Olugunji \& Adeyang, 2011).

The Nigerian corporate administrative system makes a wider and distinct gap between the corporate managers and the corporate owners. There is a complete separation of management from ownership; in that, the interest of those who control the bank as a corporation is entirely different from those who invest (shareholders) in the bank. This separation brees organizational stress especially when speculation is rife on bank failure. Share-holders and the customer-public make panic withdrawal of fund, thus weakening the banks' liquidity base more and more. According to Edwards (1992), stress in the banking institutions can be more conceptualized in terms of the relationship between management, shareholders and the customer-public. A key argument that popularize corporate governance is that it could provide the needed platform for effective governance and management of banks. In other words, it can help to bolster the confidence of the customers-public and share-holders. This study investigates this claims. More specifically, we assessed the relationship between banks' turmoils and banks corporate governance.

In analyzing the effects and consequence of bank turmoils, the paper cites the impacts on a growing economy like Nigeria and the need to curtail it. The paper drew data from 5 commercial banks using similar question posed to share-holder to test the confidence on corporate board members as a way of reducing turmoils. The Pearson Product Moment Correlation generated high relationship, but failed to yield a significant level on a t-test of curtailing bank turmoils; thus suggesting other predictive factors of bank turmoils. The point of common cord with other papers is the confirmation of connectivity of corporate governance with the health of the financial system. The paper argued that the ability to monitor the operations of the banking institution will ensure its stability and the nations economy.

The paper is organized in themes. The introduction is followed by the literature review and conceptual clarifications. Thereafter, we provide the theoretical framework that influences our discussion. The next theme show the hypothesis, the methodology and the result, and last themes shows the discussion, conclusion and recommendations.

Conceptual clarification and literature review. 


\section{Literature Review and Conceptual Clarification}

Corporate governance is defined as a set of process, customs, policies, law and institutions affecting the way a corporation is directed, administered or controlled. It is a system by which corporations are governed and controlled with a view to increasing shareholders value and meeting the expectations of the other stakeholders (CBN, 2006). Within this context, corporate governance influences how objectives of the banking institutions are set and achieved, how risk is monitored and assessed and how performance is optimized. A good governance promote goodwill, confidence and credibility of the banking institution. It increases valuation, high profit, higher sales, growth and low capital expenditure. It enhances corporate performance values as well as providing meaningful and reliable financial report on firms operation (Wollgan; 2003, Vndanga 2011).

Bank turmoil is seen by the central Bank of Nigeria as the inability of banks to meet it's capitalization requirement. These are banks which are afflicted by mismanagement. The Nigeria Deposit and Insurance Corporation (NDIC), refers to bank turmoil as a state of insolvency and liquidation. Ekpenyong (1994) in Ifeanyi et'al 2011) measure distress turmoil rate in terms of capital adequacy, asset quality, management competence, earnings, strength and liquidity sufficiency (CAMEL). When a bank can no more meets it's financial obligations, such as interbank indebtedness and depositors funds as a result of weak deposit base, a turmoils is generated.

The instability in the Nigerian banks is blamed on bad and poor corporate decisions made by bank management and directors. It is the result of misgovern, mismanaged and miscontrol of banking operations. These eventually resulted into lack of transparency, improper risk management, weak internal control system, erode of public confidence, bank turmoil and distress.

The role of banks corporate governance is to create an atmosphere which can enhance strong and reliable banking industry that ensures safety of depository money and development of effective support of the economic development through its performance.

The management of banks therefore is presumed to exercise good governance practices to avoid the consequences of failures. According to Wilson (2006) poor corporate governance can lead the market to lose confidence in the inability of the bank to properly manage it's assets and liability including deposit which could in turn trigger a bank liquidity crisis. Good corporate governance therefore helps in ensuring stability of the economy and successful realization of banks strategies (Oluyemi 2005).

According to Sanusi (2009) cited in Nnoclim (2012), weak corporate governance and unbridled corruption in the financial institutions were at the root of the banking sector crisis. They combined to cause the collapse of the banking system in 2009. The governance weakness includes; weak board oversight, poor risk management practices which resulted in unbridled risk exposure to the capital market and oil \& gas sector, technical incompetence of board members, poor board leadership, conflict of interest, insider abuse, high incidence of nonperforming loans including insider related credits. As it is the case in other sector or the economy, poor and inefficient manpower demonstrated in incompetent board members and management underlie bank distresses and failures. This realization by many authorities (CBN, 2009; Mohammed, 2012) suggests that scandals and crisis in banks can be avoided if there is good governance. It is also suggested that good corporate governance is a differentiator among companies that drives sustainable corporate growth and long term value creation.

Corporate governance as a concept can be viewed from 2 perspectives: internal corporate governance control and external corporate governance control. The internal corporate governance control monitor activities and then take corrective actions to accomplish organizational goals. It is concerned with how the structure within a corporate entity or enterprises received its basic orientation and direction. It includes monitoring by the board of directors, internal control procedure and internal auditors, balance of power, remuneration, monitoring by large share holders and monitoring by banks and other large creditors. (Walfgany, 2003; Ifeanyi, Oluguju and Deleyanj, 2011). On the other hand, the external corporate governance control encompasses the 
control external stakeholders exercise over the organization; This includes competition, debt covenant, demand for and assessment of performance information, government regulations, managerial labour market, media pressure, (Wilson, 2006) etc. The external approach involves the method that sees suppliers of finance control managers in order to ensure that their capital cannot be expropriated, and earn a return on the investment (Fundanga, 2012). The concept of corporate governance extends beyound system for directing and controlling a company to being concerned with holding the balance between economic and social goals, so as to align the interest of individuals, corporation and society. As a concept it's implies rules and regulations that ensures that a company is governed in a transparent and an accountable manner such that the enterprises survives and meet the expectation of its shareholders (I feanyi, et al, 2011).

The principles of corporate governance ensure the "acceptance by management of the inalienable right of shareholders as the true owners of the corporation and of their own role as trustees. It is about commitment to values about ethnical business conduct and about making a distinction between personal and corporate funds in the management of a company. Corporate governance therefore influences how the objectives of the company are set and achieves, how risk is monitored and assess and how performance is optimized (Khan, 2011). Within this context corporate governance becomes much more than an academic concept. This is because of the banks dominant role in the financial sector. It is the main sources of finance in the economy. The failure of corporate governance in banks poses serious consequence for the banking sector and economy at large. The Bassel Committee on Banking(2010) state that, effective corporate governance practices are essential for achieving and maintaining public trust and confidence in the banking system, which is critical to the proper functioning of the banking sector and economy as a whole. In Fundanga's (2011), analysis, a poor corporate governance can lead to financial markets losing confidence in the ability of banks to properly manage their asset and liabilities including customers deposits, and this could trigger a rush on banks or precipitate a liquidity crisis.

An assessment from the recent financial crisis in the Nigerian banking sectors shows that, excessive exposure, concentration, poor credit policies and inadequate management, failure of credit risks showed where indices of weak and poor corporate governance by the board of directors, shareholders and management team generally (Oluyemi, 2005).

Elsewhere, Fundanga (2011) examined the failure in the Zambian banking sector and argued that the turmoil (failure) in the banks was the result of weak governance which reflected in large credit exposure, lending policy, incompetent management, coupled with ineffective boards, foreign exchange exposure, inadequate risk management from work, the issue of the board chairman being the chief executive and the highest shareholders of the bank.

On the similar note, Sanusi the CBN Governor of Nigeria called on the directors of banks and other financial institutions in Nigeria to steer clear of activities capable of compromising adequate corporate governance practices in their respective company. "Weak corporate governance and unbridled corruption at financial institutions were at the root of the banking sector crisis that almost led to the collapse of the system in 2009. The CBN Governor identified such weakness to include weak board oversight, poor risk management practice, insiders abuse and conflict of interest. Other factors that weakens the effectiveness of the banks includes; poor quality financial disclosure, ineffective external auditors and lack of independent directors on the board of banks.

\section{Theoretical Framework}

The theory used in this study is agency theory. In Jensern and Mechling's (1976) analysis, agency relationship is defined as a type of contract in which the principal keep the agent to carry out the services of the firm on his behalf. In relation to corporate governance, agency theory assumed a two tier form of firm control which involves the manager and owners (agent and principal). In this relationship, agency theory holds that there will be some frictions and mistrust between the two groups. The basic structure of the corporation is the web of contractual relationship among the 
different interest groups with a stake in the company. The agency problem therefore arises due to the different interest and the conflict between the ownership and the control as the principal delegates some decision making authority to the agent. This delegated authority reduces the value and maximizes decisions taken by the managers in the firm. The key prediction of the theory is that frictions and mistrust among the different interest groups affect the effectiveness and efficiency of the organization.

Since corporate governance in Banks implies that banking institutions should strike a balance between the interest of bank management, shareholders and stakeholders in all levels of organizations, we investigate the extent to which discrepancy in striking the balance contribute to bank turmoil. The banks normally would want to reduce risk, the share holders would want to reasonably maximize profit, whereas the managers is interested in creating and making profit. Agency model, holds that firms are basically units of conflict rather than unitary profit-seeking machinery; this conflicts directly affect the structure of banking institution, and the outcome of corporate governance in creating transparency and safeguards against the threat of mismanagement and corruption in the banking system. Research inspired by agency theory has demonstrated that in acting as an intermediary for other people's financial transactions and as custodian of their financial asset, agent are often forced to choose among the competing interest of others and weigh them against their own. This conflict primarily arises as a result of trying to provide as many possible services as they can to different parties at the same time (Jensern \& Mechling, 1976, cited in Khan, 2011).

\section{Research hypothesis}

- Ho: There is no significance relationship between bank turmoils and bank corporate governance.

- Hi: There is a significance relationship between bank turmoils and bank corporate governance.

\section{Methodology of the Study}

The study population consists of 10 commercial banks in Nigeria, but we drew sample from 5 of them because their data were more comprehensive than others. These banks include UBA, Union Banks, First Bank, Eco Bank and Unity Bank. The research used was survey method of questionnaire and secondary data collected from a 5 years annual audited financial report of the above banks from (2006-2011) i.e. 5 years period. The data were analysed using Pearson Product Moment Correlation Coefficient.

\section{Model of Specification}

The raw score or computational formula for computing the Pearson $(r)$ is given by:

$$
r=\frac{N \Sigma X Y-\Sigma X \Sigma Y}{\sqrt{\left[( N \Sigma X ^ { 2 } - ( \Sigma X ) ^ { 2 } ] \left[\left(N \Sigma Y^{2}-(\Sigma Y)^{2}\right]\right.\right.}}
$$

From the statistical formular above:

$\mathrm{N}=$ Response options

$X=$ Response options points, independent variables

$Y=$ No. of respondents, dependent variables, interpretation of correlation coefficient.

The correlation coefficient is an index of the extent of relationship between the variables. It can take values from -1.00 through 0 to +1.00 inclusive. The end point of the interval which is +1.00 indicates a perfect correlation between the two variables. Correlation indicating " 0 " shows no relationship. The positive sign (+) shows positive relationship, while the negative sign (-) shows 
negative relationship. Positive relationship indicate that high scores on the variables relates to high scores in the second variables while negative relationship indicate that high scores on one relate with low scores on the other.

\section{Variables}

The hypothesis was further tested to consider whether the variables were valid for the purpose, by computing the variances, standard error i.e. standard deviation then t-calculation and t-critical at $5 \%$ level of significance $3 \mathrm{df}$, for 2 tailed test. The decision role accept null hypothesis if t-calculated $<$ t critical or reject, if t critical < t calculated.

\section{Result}

The data was analysed and hypothesis tested as shown below:

- Ho: There is no significance relationship between bank turmoils and bank corporate governance.

- Hi: There is a significance relationship between bank turmoils and bank corporate governance.

To test the hypothesis, the used the responses there share-holders provide to the following questions; "Are you satisfied at the appointment of board of directors and management mix in your bank as appointed on the basis of their professional skills, technical experience field of specialization and independency?".

The responses were measured on a six-point likert scale which ranged from $6=$ very strongly satisfied, (VSS), 5=strongly satisfied (SS), 4= Satisfied, (S) 3= Dissatisfied (DS) 2 = strongly dissatisfied (SD), 1 = very strongly dissatisfied (VSD).

\section{Calculation of Correlation}

\begin{tabular}{|l|c|c|c|c|c|}
\hline Options & Point $(\mathrm{x})$ & Response $(\mathrm{y})$ & $\mathrm{XY}$ & $\mathrm{X}^{2}$ & $\mathrm{Y}^{2}$ \\
\hline VSS & 6 & 18 & 108 & 36 & 324 \\
\hline SS & 5 & 38 & 190 & 25 & 1444 \\
\hline S & 4 & 30 & 120 & 16 & 900 \\
\hline DS & 3 & 14 & 42 & 9 & 196 \\
\hline SDS & 2 & 13 & 26 & 4 & 169 \\
\hline VSDS & 1 & 7 & 7 & 1 & 49 \\
\hline SUM $\Sigma$ & 21 & 120 & 493 & 91 & 2886 \\
\hline
\end{tabular}

$N=6, \Sigma X=21, \Sigma Y=120, \Sigma X Y=493, \Sigma X^{2}=91$ and $\Sigma Y^{2}=2886$.

$r=N \Sigma X Y-\Sigma X \Sigma Y$

$\sqrt{\left[\left(N \Sigma X^{2}-(\Sigma X)^{2}\right]\left[\left(N \Sigma Y^{2}-(\Sigma Y)^{2}\right]\right.\right.}$

Substituting

$r=6 \times 493-21 \times 120$

$\sqrt{\left[\left(6 \times 91-(21)^{2}\right]\left[\left(6 \times 2886-(120)^{2}\right]\right.\right.}$

$r=\underline{2958-2520}$

$\sqrt{105 \times 2916}=438$

$553=0.79$

The correlation coefficient $r=0.79$.

A very high correlation coefficient, signifying greater confidence by the share holders. We interpret this to mean less conflicts between the shareholders, the customers, public and the management team and by extension that a strong relationship exist between shareholders and 
corporate governance. But a test of the high relationship with bank turmoil was not significant.

To test the hypothesis we use, a 2 tail test

$$
\begin{aligned}
& t=\frac{r \sqrt{N-2}}{1-r^{2}} \\
& \text { Where } r=0.79 \\
& \mathrm{~N}=6 \\
& =0.79 \sqrt{\frac{6-2}{1-0.79}} \\
& =0.79 \sqrt{\frac{4}{0.376}} \\
& =0.79 \sqrt{10.64} \\
& =0.79(3.26) \\
& =2.58 \\
& \mathrm{t}-\mathrm{cal}=2.58, \mathrm{df}=4 \\
& \text { critical value at } 0.05 \text { at } 4 \mathrm{df}=2.78 \\
& \text { critical value at } 0.01 \text { at } 4 \mathrm{df}=2.13
\end{aligned}
$$

\section{Decision}

Since the t-calculated of 2.58 is less than t-critical at $95 \%$ and $99 \%$ significance level $(2.78$ and 2.13 respectively), we conclude that establishing a high relationship between shareholder and bank's management team may not necessarily predict the end of bank turmoil. As the literature would show several other factors (both internal and external) to the banking environment causes bank turmoils.

From this we conclude that effective implementation of corporate governance code of conduct for Banks will enforce the appointment of banks board of directors and management to be only professional with technical skills, experience and due care who are capable of working independently without fear or threat may reduce turmoil in terms of the relationship between shareholders and management; but turmoil as it relates to bank failures will require the investigation of others related variables, including corruptions, the management of the macro economy, global market trend etc.

\section{Discussion of Findings}

The respondents agreed that specialist and professional with adequate and relevant skills and knowledge should be the directors, management and heads of departments in our banks for adequate enabling environmental of professional and technical competences and practices in the banks. Beyond this the need for transparency and fairness in banks, lending and investment is a critical requirement.

Reputation risk is a critical factor that can affect a bank seriously if a good corporate governance practices and customers services standard is not good enough to build public confidence in the credibility of the banks operations. This is because banks operate in a volatile environment, where perceptions in their dealings could trigger a run on a banks deposit. From the data gathered and analysed, it shows that the new code of conduct for corporate governance for banks if adhered to will reduce the turmoils especially those that have to do with the shareholders. A good and effective corporate governance, may removed any existing ills or consequences posed on the banking sector and the financial sector of the economy. This will safeguard the integrity of the banks. A prudent and transparent banking sector is also seen to be possible if the directors and managers could stick to the banking policies and objectives.

Else where research have shown that, sound corporate governance is fundamental to 
effective risk management. The present of a well regulated financial sector and properly run corporate entities is the key to the prosperity of any economy;

- Effective and good corporate governance enhances transparency, trust and builds reputation;

It builds public confidence in the credibility of the banks operation;

It boost the finance and the economy of the nation; and Makes active concern with understanding of and diligent discharge of responsibility in a prudent manner (Ifeanyi, Olugunji \& Adeyani, 2011)

It create room for adequate operation and financial control, as well as Integration and development of information, technology system; accounting system and records. (Oluyemi, 2005).

- Effective integration of entitles technical competences, good leadership and administrative ability;

robust risk management and discharge loan of information, and adequate management capacity (Edwards, 1992)

- Strong internal controls compliance with laid down internal control and operation procedures; understanding between board and management; and effective management information system (Osuka \& Mpamugoh, 2006

Evidence from the distressed banks shows that managers and directors in most of our banking institutions were becoming an uncontrollable monster and self perpetrating oligarchy. Some of them who convicted were asked to forfeit the ill gotten property, numbering into millions of naira. Given this situation therefore appropriate corporate governance reforms is a welcome development. But beyond this, other measures, such as the use of supervisory bodies, international standard corporate governance code, corporate governance assessment 2007, legal principles like the 2004 new consolidation and reconstruction of vide lines for mergers and acquisition for global market competitions, would have to be implemented in Nigeria.

In the early years of banking business in Nigeria, banking turmoil in Nigeria were controlled through measures such as banking ordinance of 1952, establishment of the central bank of Nigeria (CBN) in 1958 to serve as a regulatory body of banks, the development of structural adjustment programme in 1986, the establishment of NDIC in 1988, the introduction of the consolidation policy in 2002 by CBN, the increased capital based to N2.5 billion in form of financial system reforms by the CBN in 2004. This reforms led to the withdrawal of public sector fund amounting to N74 million, it's led to mergers and acquisition which reduced the number of banks in the country from 89 to 25. It also led to the review of the existing code for the Nigerian banks that brought about the development of 2006 code of corporate governance for banks in Nigeria. Post consolidation and proper auditing as well as honest checks on the operation of these banks will have to be embarked upon to avoid the embarrassment on the economy that bank turmoils generate.

Finally, the research work, shows that good corporate governance will put in place certain board committees such as the Audit, risk management, and loan review committees to ensure independence transparency and accountability to board oversight over management actions, this is to ensure that safeguards are put in place for effective oversight of management and to improve professional ethics in our banking industries.

\section{Conclusion}

In view of the research analysis and findings, it can be concluded that corporate governance can only prevent banking turmoil only if it is properly and adequately implemented with active concerned with understanding and diligent discharge of responsibility in a prudent manner. There must be a strict adhesion to the rules, regulations, laws, requirement expectations and ethics of the banking system. 


\section{Recommendations}

- The turmoil of distress, instability and deviance in our banking industry will reduce to the bearest minimum, and removed in total, if our board and management of banks can adhere to the principles and practice of good and effective corporate governance as their tools and mandate of administration.

- The board of directors, management team and the entire staff pool of the banks should have adequate relevant knowledge and professional capacity for their different offices to be able to perform adequately, their critical technical, strategic and tactical roles in the governance structure and operational demands of the banks.

- The bank regulatory bodies should act as soldiers to all the banks in the country so as to monitor and enforce the effective corporate governance practice.

- The employment and recruitment activities should not based on "man know man" but based on proper employment system of proper qualification and experience.

- The banking laws, requirement and the expectation gab should be filled by continuous and prompt monitoring and checks by the joint bank and government body.

- The NDIC, CBN, EFCC, IPC and other regulatory and disciplinary body should joined forces to strongly implement and measure any weakness deviance, or turmoil that might want to arise in the form of supervision, risk management, loan granting, boards and management selection and appointment of rank and file.

\section{References}

CBN Code of corporate governance for banks in Nigeria, post consolidation.

Fatimoh, M. (2012) "Impact of corporate governance on Banks performance in Nigeria Journal of emerging trends in economic and management science. Etems 2(3) 257-200.

Edwards, J. R (1992) A cybernetic theory of stress, coping and well-being in organization academy of management review,: 17, 258-274.

Feakandu, A. (2012); Banking crisis, CBB resolution. Blue print. Com Newspaper 2013.

Fundanga C. (2011). Corporate governance and its impact on financial institution BIS central bankers' speeches Lasaka.

Ifeanyi, D, Olugunju, A, Adeyanj O. (2011) "Corporate governance and bank failure in Nigeria: Issues, Challenges and opportunity. Research journal of finance and accounting V. 2 (2) pp www.hste.org.

Khan, H. (2011) A literature review of corporate governance. Investment conference on E-business management and economic IPEDR vol. 125 C LACSIT Press Singapore.

Ogbuokiri, P (2009); Daily Champion Nigeria: Banking sector: The turmoil the crisis @ 2013 HHP./www.champion.com.ng

Okechukwe, N. (2012); CBN canvasses efficient corporate governance for financial institution: A key note address presented by CBN governor at continuous education training centre.

Oluyemi, S. (2005) Banking sector reforms and the imperatives of good corporate governance in Nigerian banking system". w.w.w.ndic.ng.com/pdf/egbok.pp 1-33.

Osuka, Bernado and Chris Mpamugoh (2006) "Restructuring Distressed Financial systems "The Nigerian Bankers".

Walfgany D. (2003). The impact of corporate governance on firms performance. Department of corporate finance, University of Basel w.w..

Wilson I. (2006) "Regulatory and institution challenges of corporate governance in Nigeria post banking consolidation. The Nigerian economic summit groups (MSESC) PP 1-9. 
